\title{
INDICATORS OF THE ELEMENT RANGE OF RAT'S BLOOD IN TERM ARTIFICIAL HYPOBYOSIS
}

\author{
Anna Umanska \\ Academician M. F. Guliy Department of Biochemistry \\ National University of Life and Environmental Sciences of Ukraine \\ 15 Heroiv Oborony str., Kyiv, Ukraine, 03041 \\ ann.umanska@ukr.net \\ Dmytro Melnichuk \\ Head of Public Organization \\ Public Organization "The Council of Heroes of Ukraine in the agroindustrial complex" \\ 2 a Solomianska str., Kyiv, Ukraine, 02000 \\ kalachnyuk_liliya@nubip.edu.ua \\ Lilia Kalachnyuk \\ Academician M. F. Guliy Department of Biochemistry \\ National University of Life and Environmental Sciences of Ukraine \\ 15 Heroiv Oborony str., Kyiv, Ukraine, 03041 \\ kalachnyuk_liliya@nubip.edu.ua
}

\begin{abstract}
The promising method of anesthesia and anesthesia is the state of artificial hypobiosis. Hypercapnia is a prerequisite for creating an artificial carbon dioxide hypobiosis, along with hypoxia and hypothermia. Adhering to the conditions under which the state of artificial carbon dioxide hypobiosis is created, animals reduce the level and intensity of metabolic processes both in the body as a whole and in separate organs. In order to investigate the safety of the hypobiological state and evaluate its applicability in clinical practice, it is necessary to investigate the functional characteristics of the blood. One of the most important indicators is the change of elemental composition. After all, the set of micro-and macro-elements is involved in the enzymatic reactions of the organism, its metabolic processes.

Therefore, the aim of the study was to investigate the elemental changes in the blood of rats for artificial hypobiosis. In experiments, white non-breeding male rats weighing 180-200 g were used, which were maintained under standard vivarium conditions. Animals were divided into 2 groups: control and experimental (the state of artificial hypobiosis). Each group had 7 animals. Measurement of the content of macro- and micronutrients was carried out using a mass spectrometric ionization method in an inductively coupled plasma on an IRIS Interband II XSP device manufactured by Thermo Scientific, USA. The results of the study were processed and presented using the methods of statistical analysis, namely: the method of descriptive statistics; Shapiro-Wielka's criterion for choosing a statistical criterion for comparing groups; Student's criterion; Mann-Whitney's criterion. Results of evaluation of dynamics in the experimental (hypobiotic) group using the criterion of sign-marks of Wilcoxon. As a result of the studies, increased levels of Sodium, Ferrum, Calcium were observed, while the content of Nickel and Barium reduced. The results of the analysis of the dynamics of blood parameters in the experimental group by the methods of descriptive statistics showed significant changes in such elements as: Potassium, Sodium, Ferrum, Calcium, Magnesium. The heterogeneity of the results of the experimental and control groups according to the Mann-Whitney criterion was demonstrated in the following elements: Potassium, Sodium, Ferrum, Calcium, Chromium, Strontium.
\end{abstract}

Keywords: hypobiosis, hypercapnia, hypoxia, blood, macroelements, microelements.

\section{Introduction}

The state of artificial hypobiosis is a common concern among scientists, because there is a rather large prospect of using its model in medicine, veterinary and livestock as a way of general anesthesia, canning of biological material, therapeutic method, etc. [1]. The mechanic of biochemical transformations, which undergoes the transition of organisms to the hypometabolic level of vital activity, remains unclear. Also, if it possible to apply this method in clinical practice. Previously, researchers have already studied the biochemical features of this condition in cardiomyocytes, name- 
ly, the indicators of oxidative phosphorylation. Analyzing the obtained results, it should be noted that under the conditions of artificial hypobiosis a partial decoupling of oxidative phosphorylation processes in mitochondria of cardiomyocytes of rats is observed for the use of substrate - malate and is not observed for the use of succinate [2]. Therefore, it is possible to suppose the suppression of the functional activity of the first link of the oxidation and phosphorylation of the respiratory chain, taking into account that at the same time no changes in the functional activity of the final link of the conjugation were detected. The obtained results confirm the possibility of endogenous regulation of hypobiosis by modifying the functional activity of individual parts of the respiratory chain of mitochondria, for example, as with the use of inhibitors of the respiratory chain [3]. In addition, the detected increase in succinate-CoQ-oxidoreductase activity of membrane preparations indicates the possibility of switching cardiomyocytes to succinate type of tissue respiration, which results in maintenance of the necessary energy supply, since the heart should function in sufficient mode, including for hypobiosis. Perhaps this also results in the absence of significant changes in ATP-hydrolase activity, which indicates the adequacy of energy formation under such conditions. Partial inhibition of oxidative phosphorylation in cardiomyocytes may be due not to the transition of mitochondria to heat supply [4], but with a decrease in the frequency of cardiac contractions and, correspondingly, to a decrease in the need for ATP.

However, changes in mineral metabolism occurring in the state of artificial hypobiosis have not yet been investigated. A detailed study of physiological changes in the main organs of the liver, heart and blood of rats will allow to assess the risks of using this method in clinical practice. Therefore, the purpose of the study was to investigate the elemental blood composition of rats for artificial hypobiosis. As a result of the studies was observed the growth of such elements as: Sodium, Ferrum, Calcium, and the decrease of Nickel, Barium. In the state of artificial hypobiosis in animals, there was a decrease in the frequency of cardiac contractions, a decrease in the intensity of respiration, lack of mobility of the organism.

\section{Aim of research}

Show elemental changes in the blood of rats in term of artificial hypobiosis. These indicators will make it possible to assess the safety of artificially created hypobiotic conditions and to evaluate the possibility of using this method in medical practice.

\section{Materials and methods}

The study was conducted on the basis of the State University "Institute of Pharmacology and Toxicology of the National Academy of Medical Sciences of Ukraine”, 2016-2017 years.

In experiments, white non-breeding male rats weighing 180-200 g were used, which were maintained under standard vivarium conditions. Animals were divided into 2 groups: control and experimental (the state of artificial hypobiosis). Each group had 7 animals.

All studies were conducted in accordance with the requirements of the "European Convention for the Protection of Vertebrate Animals Used for Experimental and Other Scientific Purposes" (Strasbourg, France, 1985), on the general ethical principles of experiments on animals adopted by the First National Congress of Bioethics in Ukraine (2001) [5].

The results of the study were processed and presented using the following statistical analysis methods, namely:

- method of descriptive statistics;

- results of check the normality of the data distribution using the Shapiro-Wielka criterion for choosing a statistical criterion for comparing groups;

- results of comparison of the experimental and control groups using Student's criterion;

- results of comparison of experimental and control groups using the Mann-Whitney criterion;

- results of the estimation of dynamics in the experimental (hypopoietic) group using the criterion of Wilcoxon signed-rank test [6].

Animals were placed in a hermetically sealed chamber, which had volume $3 \mathrm{dm}^{3}$ at ambient temperature $3-4{ }^{\circ} \mathrm{C}$ for introduction into the state of artificial hypobiosis. During the stay 
of animals in the chamber under such conditions, both the temperature and the composition of the gaseous medium changed: hypercapnia (increased carbon dioxide content) and hypoxia (the level of oxygen decreased). After 3-3.5 hours, depending on the individual characteristics of the animals, there was a decrease in rectal temperature from $37{ }^{\circ} \mathrm{C}$ to $16^{\circ} \mathrm{C}$; reduction of heart rate from 380 to 80 beats per minute; the animals completely lost their mobility, the reaction to the pain stimulus and disappeared reflex to the position, indicating the development of the state of artificial hypobiosis [7].

Blood was taken from the heart's aorta of the rat. Sample mineralization and preparation of calibration solutions were carried out using nitric acid. Measurements of the content of macro- and micronutrients were performed by mass spectrometric ionisation in inductively coupled plasma on the IRIS Interband II XSP device, manufactured by Thermo Scientific, USA [8].

\section{Results}

As a result of the research, it was found that in the state of artificial hypobiosis the content of such elements increases: Sodium, Ferrum, Calcium, but the content of Nickel and Barium decreases, as shown in Table 1.

Also, it is enough to note that after exiting from the state of artificial hypobiosis, increased excitability of rats was observed. This is due to the fact that after hypobiotic conditions, which reduces the vital functions of the organism: reduced heart rate, suppressed metabolic processes of the body, there is a complete loss of mobility of the organism.

\section{Table 1}

Results of comparative analysis of blood of rats of control and experimental groups by methods of descriptive statistics

\begin{tabular}{|c|c|c|c|c|c|c|c|c|}
\hline Microelement & Group & $\mathbf{n}$ & $\mathbf{M}$ & Me & $\mathrm{CB}$ & MIN & MAX & p \\
\hline \multirow{2}{*}{$\mathrm{K}$} & Control & 7 & 1953.1 & 1961.0 & 41.5 & 1861.0 & 1981.0 & \multirow{2}{*}{$0.038^{\mathrm{a}}$} \\
\hline & Experiment & 7 & 1979.9 & 1995.6 & 42.7 & 1885.6 & 2005.6 & \\
\hline \multirow{2}{*}{$\mathrm{Na}$} & Control & 7 & 1794.4 & 1766.4 & 50.0 & 1747.4 & 1847.4 & \multirow{2}{*}{$0.001^{\mathrm{a}}$} \\
\hline & Experiment & 7 & 1644.9 & 1702.1 & 78.7 & 1502.1 & 1702.1 & \\
\hline \multirow{2}{*}{$\mathrm{Fe}$} & Control & 7 & 501.4 & 492.8 & 36.3 & 482.8 & 582.8 & \multirow{2}{*}{$0.002^{\mathrm{a}}$} \\
\hline & Experiment & 7 & 572.6 & 601.2 & 48.80 & 501.2 & 601.2 & \\
\hline \multirow{2}{*}{$\mathrm{Ca}$} & Control & 7 & 67.13 & 65.28 & 4.98 & 62.28 & 74.28 & \multirow{2}{*}{$0.017^{\mathrm{a}}$} \\
\hline & Experiment & 7 & 71.19 & 75.48 & 5.35 & 65.44 & 75.48 & \\
\hline \multirow{2}{*}{$\mathrm{Mg}$} & Control & 7 & 41.20 & 38.62 & 5.16 & 36.62 & 48.62 & \multirow{2}{*}{$0.892^{6}$} \\
\hline & Experiment & 7 & 41.55 & 39.84 & 4.53 & 37.84 & 47.84 & \\
\hline \multirow{2}{*}{$\mathrm{Zn}$} & Control & 7 & 7.09 & 6.84 & 0.85 & 5.54 & 7.88 & \multirow{2}{*}{$0.128^{\mathrm{a}}$} \\
\hline & Experiment & 7 & 7.46 & 7.03 & 0.53 & 7.03 & 8.03 & \\
\hline \multirow{2}{*}{$\mathrm{Cu}$} & Control & 7 & 1.65 & 1.62 & 0.09 & 1.52 & 1.82 & \multirow{2}{*}{$0.318^{\mathrm{a}}$} \\
\hline & Experiment & 7 & 1.75 & 1.61 & 0.38 & 1.51 & 2.61 & \\
\hline \multirow{2}{*}{$\mathrm{Cr}$} & Control & 7 & 0.745 & 0.696 & 0.0776 & 0.686 & 0.886 & \multirow{2}{*}{$0.001^{\mathrm{a}}$} \\
\hline & Experiment & 7 & 0.581 & 0.568 & 0.0386 & 0.558 & 0.668 & \\
\hline \multirow{2}{*}{$\mathrm{Mn}$} & Control & 7 & 0.713 & 0.679 & 0.0522 & 0.669 & 0.769 & \multirow{2}{*}{$0.128^{\mathrm{a}}$} \\
\hline & Experiment & 7 & 0.695 & 0.661 & 0.0650 & 0.601 & 0.761 & \\
\hline \multirow{2}{*}{$\mathrm{Tl}$} & Control & 7 & 0.505 & 0.484 & 0.0639 & 0.404 & 0.574 & \multirow{2}{*}{$0.259^{\mathrm{a}}$} \\
\hline & Experiment & 7 & 0.442 & 0.466 & 0.0744 & 0.306 & 0.506 & \\
\hline \multirow{2}{*}{$\mathrm{Ba}$} & Control & 7 & 0.191 & 0.200 & 0.0693 & 0.105 & 0.309 & \multirow{2}{*}{$0.383^{\mathrm{a}}$} \\
\hline & Experiment & 7 & 0.139 & 0.129 & 0.0407 & 0.109 & 0.229 & \\
\hline \multirow{2}{*}{$\mathrm{Ni}$} & Control & 7 & 0.190 & 0.189 & 0.0090 & 0.179 & 0.199 & \multirow{2}{*}{$<0.001^{\sigma}$} \\
\hline & Experiment & 7 & 0.080 & 0.079 & 0.0068 & 0.068 & 0.088 & \\
\hline \multirow{2}{*}{$\mathrm{Sr}$} & Control & 7 & 0.066 & 0.066 & 0.0058 & 0.056 & 0.076 & \multirow{2}{*}{$0.007^{\mathrm{a}}$} \\
\hline & Experiment & 7 & 0,072 & 0,068 & 0,0053 & 0,068 & 0,078 & \\
\hline
\end{tabular}

Note: calculated using Mann-Whitney's criterion; calculated using Student's criterion for independent samples 
The results of checking the normality of the data distribution of the experimental and control groups using the Shapiro-Wielka criterion are given in Table 2. By this criterion, a significant difference from the results of the control group was shown on such elements as: Potassium, $\mathrm{Cu}-$ prum, Chromium, Zinc, Barium and Strontium.

Table 2

The results of checking the normality of the data distribution of control and experimental groups using the Shapiro-Wielka criterion

\begin{tabular}{|c|c|c|c|c|c|c|}
\hline Microelement & Group & $\begin{array}{c}\text { Shapiro-Wielka } \\
\text { statistics }\end{array}$ & df & $\mathbf{p}$ & $\begin{array}{c}\text { Conclusion consider- } \\
\text { ing normality }\end{array}$ & Criterion \\
\hline \multirow{2}{*}{$\mathrm{K}$} & Control & 0.641 & 7 & 0.001 & Not normal & \multirow{2}{*}{ Mann-Whitney } \\
\hline & Experiment & 0.636 & 7 & 0.001 & Not normal & \\
\hline \multirow{2}{*}{$\mathrm{Na}$} & Control & 0.739 & 7 & 0.010 & Not normal & \multirow{2}{*}{ Mann-Whitney } \\
\hline & Experiment & 0.769 & 7 & 0.020 & Normal & \\
\hline \multirow{2}{*}{$\mathrm{Fe}$} & Control & 0.565 & 7 & 0.000 & Not normal & \multirow{2}{*}{ Mann-Whitney } \\
\hline & Experiment & 0.600 & 7 & 0.000 & Not normal & \\
\hline \multirow{2}{*}{$\mathrm{Ca}$} & Control & 0.762 & 7 & 0.017 & Normal & \multirow{2}{*}{ Mann-Whitney } \\
\hline & Experiment & 0.665 & 7 & 0.002 & Not normal & \\
\hline \multirow{2}{*}{$\mathrm{Mg}$} & Control & 0.751 & 7 & 0.013 & Normal & \multirow{2}{*}{ Student's } \\
\hline & Experiment & 0.783 & 7 & 0.028 & Normal & \\
\hline \multirow{2}{*}{$\mathrm{Zn}$} & Control & 0.834 & 7 & 0.087 & Normal & \multirow{2}{*}{ Mann-Whitney } \\
\hline & Experiment & 0.665 & 7 & 0.002 & Not normal & \\
\hline \multirow[b]{2}{*}{$\mathrm{Cu}$} & Control & 0.889 & 7 & 0.267 & Normal & \multirow{2}{*}{ Mann-Whitney } \\
\hline & Experiment & 0.590 & 7 & 0.000 & Not normal & \\
\hline \multirow{2}{*}{$\mathrm{Cr}$} & Control & 0.792 & 7 & 0.034 & Normal & \multirow{2}{*}{ Mann-Whitney } \\
\hline & Experiment & 0.525 & 7 & 0.000 & Not normal & \\
\hline \multirow{2}{*}{$\mathrm{Mn}$} & Control & 0.696 & 7 & 0.003 & Not normal & \multirow{2}{*}{ Mann-Whitney } \\
\hline & Experiment & 0.819 & 7 & 0.062 & Normal & \\
\hline \multirow{2}{*}{$\mathrm{Tl}$} & Control & 0.889 & 7 & 0.268 & Normal & \multirow{2}{*}{ Student's } \\
\hline & Experiment & 0.852 & 7 & 0.127 & Normal & \\
\hline \multirow{2}{*}{$\mathrm{Ba}$} & Control & 0.875 & 7 & 0.204 & Normal & \multirow{2}{*}{ Mann-Whitney } \\
\hline & Experiment & 0.677 & 7 & 0.002 & Not normal & \\
\hline \multirow{2}{*}{$\mathrm{Ni}$} & Control & 0.818 & 7 & 0.062 & Normal & \multirow{2}{*}{ Student's } \\
\hline & Experiment & 0.886 & 7 & 0.254 & Normal & \\
\hline \multirow[b]{2}{*}{$\mathrm{Sr}$} & Control & 0.811 & 7 & 0.053 & Normal & \multirow{2}{*}{ Mann-Whitney } \\
\hline & Experiment & 0.664 & 7 & 0.001 & Not normal & \\
\hline
\end{tabular}

Results of the comparison of the elemental blood composition of the rats in the two groups (control and experimental) by some indicators using Student's criterion for independent samples, as shown in Table. 3, but using the Mann-Whitney criterion in Table. 4, 5

Table 3

Results of comparison of control and experimental groups using Student's criterion

\begin{tabular}{cccccc}
\hline Variable & t & df & p-meaning & $\begin{array}{c}\text { The difference in } \\
\text { averages }\end{array}$ & $\begin{array}{c}\text { Conclusion regarding the } \\
\text { homogeneity of groups }\end{array}$ \\
\hline $\mathrm{Mg}$ & -0.138 & 12 & 0.892 & -0.359 & Homogeneous \\
$\mathrm{Ni}$ & 25.882 & 12 & $<0.001$ & 0.111 & Not homogeneous
\end{tabular}

Note: the conclusion is made at a significance level of 0.05

The heterogeneity of the results of the experimental and control groups according to the Mann-Whitney criterion was demonstrated in the following elements: Potassium, Sodium, Ferrum, Calcium, Chromium, Strontium. Additional rank statistics obtained from the comparison of control and experimental groups using the Mann-Whitney criterion were also demonstrated. The results are shown in the Table 5. 
Table 4

Results of the comparison of the elemental composition of the control and experimental groups of rats using the Mann-Whitney criterion

\begin{tabular}{cccccc}
\hline Variable & Mann-Whitney $\mathbf{U}^{*}$ & Wilcoxon W & $\mathbf{Z}$ & p-meaning & Homogeneity of groups** \\
\hline $\mathrm{K}$ & 8 & 36 & -2.113 & 0.038 & Not homogeneous \\
$\mathrm{Na}$ & 0 & 28 & -3.187 & 0.001 & Not homogeneous \\
$\mathrm{Fe}$ & 2 & 30 & -2.950 & 0.002 & Not homogeneous \\
$\mathrm{Ca}$ & 6 & 34 & -2.398 & 0.017 & Not homogeneous \\
$\mathrm{Zn}$ & 12 & 40 & -1.621 & 0.128 & Homogeneous \\
$\mathrm{Cu}$ & 16 & 44 & -1.096 & 0.318 & Homogeneous \\
$\mathrm{Cr}$ & 0 & 28 & -3.220 & 0.001 & Not homogeneous \\
$\mathrm{Mn}$ & 12 & 40 & -1.626 & 0.128 & Homogeneous \\
$\mathrm{Tl}$ & 15 & 43 & -1.219 & 0.259 & Homogeneous \\
$\mathrm{Ba}$ & 17.5 & 45.5 & -0.897 & 0.383 & Homogeneous \\
$\mathrm{Sr}$ & 4 & 32 & -2.691 & 0.007 & Not homogeneous
\end{tabular}

Note: *-rank statistics are shown in the table. $5 ; * *$ - the conclusion is made at the level of significance 0.05

Table 5

Additional rank statistics obtained when comparing control and experimental groups using the MannWhitney criterion

\begin{tabular}{|c|c|c|c|c|}
\hline Variable & Group & $\mathbf{N}$ & Average rank & Sum of ranks \\
\hline \multirow{3}{*}{$\mathrm{K}$} & Control & 7 & 5.14 & 36 \\
\hline & Experiment & 7 & 9.86 & 69 \\
\hline & Control & 14 & & \\
\hline \multirow{3}{*}{$\mathrm{Na}$} & Experiment & 7 & 11.00 & 77 \\
\hline & Control & 7 & 4.00 & 28 \\
\hline & Experiment & 14 & & \\
\hline \multirow{3}{*}{$\mathrm{Fe}$} & Control & 7 & 4.29 & 30 \\
\hline & Experiment & 7 & 10.71 & 75 \\
\hline & Control & 14 & & \\
\hline \multirow{3}{*}{$\mathrm{Ca}$} & Experiment & 7 & 4.86 & 34 \\
\hline & Control & 7 & 10.14 & 71 \\
\hline & Experiment & 14 & & \\
\hline \multirow{3}{*}{$\mathrm{Zn}$} & Control & 7 & 5.71 & 40 \\
\hline & Experiment & 7 & 9.29 & 65 \\
\hline & Control & 14 & & \\
\hline \multirow{3}{*}{$\mathrm{Cu}$} & Experiment & 7 & 8.71 & 61 \\
\hline & Control & 7 & 6.29 & 44 \\
\hline & Experiment & 14 & & \\
\hline \multirow{3}{*}{$\mathrm{Cr}$} & Control & 7 & 11.00 & 77 \\
\hline & Experiment & 7 & 4.00 & 28 \\
\hline & Control & 14 & & \\
\hline \multirow{3}{*}{$\mathrm{Mn}$} & Experiment & 7 & 9.29 & 65 \\
\hline & Control & 7 & 5.71 & 40 \\
\hline & Experiment & 14 & & \\
\hline \multirow{3}{*}{$\mathrm{Tl}$} & Control & 7 & 8.86 & 62 \\
\hline & Experiment & 7 & 6.14 & 43 \\
\hline & Control & 14 & & \\
\hline \multirow{3}{*}{$\mathrm{Ba}$} & Experiment & 7 & 8.50 & 59.5 \\
\hline & Control & 7 & 6.50 & 45.5 \\
\hline & Experiment & 14 & & \\
\hline \multirow{3}{*}{$\mathrm{Sr}$} & Control & 7 & 4.57 & 32 \\
\hline & Experiment & 7 & 10.43 & 73 \\
\hline & Total & 14 & & \\
\hline
\end{tabular}


The results of the analysis of the dynamics of blood parameters in the experimental group by the methods of descriptive statistics showed significant changes in such elements as: Potassium, Sodium, Ferrum, Calcium, Magnesium. The results are shown in the Table 6.

Table 6

Results of analysis of the dynamics of blood parameters in the experimental group by methods of descriptive statistics

\begin{tabular}{|c|c|c|c|c|c|c|c|c|}
\hline Microelement & Time & $\mathbf{n}$ & $\mathbf{M}$ & Me & CB & MIN & MAX & p \\
\hline \multirow{3}{*}{$\mathrm{K}$} & T0 & 7 & 1979.91 & 1995.63 & 42.68 & 1885.63 & 2005.63 & \\
\hline & $\mathrm{T} 1$ & 7 & 1857.63 & 1842.25 & 59.66 & 1800.25 & 1988.00 & 0.005 \\
\hline & [T1-T0] & 7 & -122.28 & -153.38 & 76.29 & -198.38 & 12.38 & \\
\hline \multirow{3}{*}{$\mathrm{Na}$} & T0 & 7 & 1644.92 & 1702.06 & 78.68 & 1502.06 & 1702.06 & \\
\hline & $\mathrm{T} 1$ & 7 & 1835.14 & 1806.00 & 47.86 & 1805.00 & 1905.00 & $<0.001$ \\
\hline & [T1-T0] & 7 & 190.22 & 202.94 & 66.79 & 103.94 & 302.94 & \\
\hline \multirow{3}{*}{$\mathrm{Fe}$} & T0 & 7 & 572.62 & 601.19 & 48.80 & 501.19 & 601.19 & \\
\hline & $\mathrm{T} 1$ & 7 & 454.32 & 445.74 & 36.25 & 435.74 & 535.74 & 0.017 \\
\hline & [T1-T0] & 7 & -118.31 & -155.45 & 49.57 & -165.45 & -65.45 & \\
\hline \multirow{3}{*}{$\mathrm{Ca}$} & T0 & 7 & 71.19 & 75.48 & 5.35 & 65.44 & 75.48 & \\
\hline & $\mathrm{T} 1$ & 7 & 63.32 & 62.32 & 3.61 & 61.32 & 71.32 & 0.006 \\
\hline & [T1-T0] & 7 & -7.87 & -4.16 & 5.00 & -14.16 & -3.13 & \\
\hline \multirow{3}{*}{$\mathrm{Mg}$} & T0 & 7 & 41.55 & 39.84 & 4.53 & 37.84 & 47.84 & \\
\hline & $\mathrm{T} 1$ & 7 & 32.59 & 31.44 & 3.63 & 30.44 & 40.44 & 0.009 \\
\hline & [T1-T0] & 7 & -8.97 & -7.39 & 6.24 & -16.39 & 0.61 & \\
\hline \multirow{3}{*}{$\mathrm{Zn}$} & T0 & 7 & 7.46 & 7.03 & 0.53 & 7.03 & 8.03 & \\
\hline & $\mathrm{T} 1$ & 7 & 6.20 & 5.77 & 0.98 & 4.77 & 7.77 & 0.016 \\
\hline & {$[\mathrm{T} 1-\mathrm{T} 0]$} & 7 & -1.26 & -1.26 & 1.00 & -3.26 & -0.26 & \\
\hline \multirow{3}{*}{$\mathrm{Cu}$} & T0 & 7 & 1.75 & 1.61 & 0.38 & 1.51 & 2.61 & \\
\hline & $\mathrm{T} 1$ & 7 & 1.70 & 1.67 & 0.05 & 1.67 & 1.77 & 0.310 \\
\hline & [T1-T0] & 7 & -0.051 & 0.059 & 0.356 & -0.841 & 0.179 & \\
\hline \multirow{3}{*}{$\mathrm{Cr}$} & T0 & 7 & 0.581 & 0.568 & 0.039 & 0.558 & 0.668 & \\
\hline & & 7 & 0.744 & 0.688 & 0.096 & 0.685 & 0.885 & 0.017 \\
\hline & $\mathrm{T} 1$ & 7 & 0.163 & 0.120 & 0.081 & 0.117 & 0.327 & \\
\hline \multirow{3}{*}{$\mathrm{Mn}$} & [T1-T0] & 7 & 0.695 & 0.661 & 0.065 & 0.601 & 0.761 & \\
\hline & T0 & 7 & 0.664 & 0.593 & 0.111 & 0.592 & 0.892 & 0.527 \\
\hline & $\mathrm{T} 1$ & 7 & -0.032 & -0.069 & 0.125 & -0.168 & 0.231 & \\
\hline \multirow{3}{*}{$\mathrm{Tl}$} & [T1-T0] & 7 & 0.442 & 0.466 & 0.074 & 0.306 & 0.506 & \\
\hline & T0 & 7 & 0.560 & 0.503 & 0.079 & 0.503 & 0.703 & 0.022 \\
\hline & $\mathrm{T} 1$ & 7 & 0.118 & 0.097 & 0.101 & -0.003 & 0.297 & \\
\hline \multirow{3}{*}{$\mathrm{Ba}$} & {$[\mathrm{T} 1-\mathrm{T} 0]$} & 7 & 0.139 & 0.129 & 0.041 & 0.109 & 0.229 & \\
\hline & T0 & 7 & 0.259 & 0.243 & 0.069 & 0.143 & 0.343 & 0.010 \\
\hline & $\mathrm{T} 1$ & 7 & 0.120 & 0.114 & 0.086 & 0.004 & 0.224 & \\
\hline \multirow{3}{*}{$\mathrm{Ni}$} & [T1-T0] & 7 & 0.080 & 0.079 & 0.007 & 0.068 & 0.088 & \\
\hline & T0 & 7 & 0.177 & 0.175 & 0.004 & 0.175 & 0.185 & $<0.001$ \\
\hline & $\mathrm{T} 1$ & 7 & 0.097 & 0.097 & 0.006 & 0.088 & 0.107 & \\
\hline \multirow{3}{*}{$\mathrm{Sr}$} & [T1-T0] & 7 & 0.072 & 0.068 & 0.005 & 0.068 & 0.078 & \\
\hline & T0 & 7 & 0.086 & 0.083 & 0.005 & 0.083 & 0.093 & 0.002 \\
\hline & $\mathrm{T} 1$ & 7 & 0.014 & 0.015 & 0.007 & 0.005 & 0.025 & \\
\hline
\end{tabular}

Note: calculated using Mann-Whitney's criterion; calculated using Student's criterion for independent samples 
The results of checking the normality of the distribution of differences [T1-T0] using the Shapiro-Wielka criterion are given in Table 7.

\section{Table 7}

The results of checking the normality of the distribution of the differences [T1-T0] with the help of the Shapiro-Wielka criterion for choosing a statistical criterion in order to assess the significance of the dynamics of the experimental group

\begin{tabular}{cccccc}
\hline Microelement & $\begin{array}{c}\text { Shapiro-Wielka } \\
\text { statistics }\end{array}$ & df & p & $\begin{array}{c}\text { Conclusion on the normality } \\
\text { of distribution }\end{array}$ & Criterion \\
\hline $\mathrm{K}[\mathrm{T} 1-\mathrm{T} 0]$ & 0.806 & 7 & 0.047 & Normal & Student's \\
$\mathrm{Na}[\mathrm{T} 1-\mathrm{T} 0]$ & 0.855 & 7 & 0.136 & Normal & Student's \\
$\mathrm{Fe}[\mathrm{T} 1-\mathrm{T} 0]$ & 0.710 & 7 & 0.005 & Not normal & Уілкоксонаі \\
$\mathrm{Ca}[\mathrm{T} 1-\mathrm{T} 0]$ & 0.769 & 7 & 0.020 & Normal & Student's \\
$\mathrm{Mg}[\mathrm{T} 1-\mathrm{T} 0]$ & 0.936 & 7 & 0.606 & Normal & Student's \\
$\mathrm{Zn}[\mathrm{T} 1-\mathrm{T} 0]$ & 0.787 & 7 & 0.030 & Normal & Yiлкоксонаi \\
$\mathrm{Cu}[\mathrm{T} 1-\mathrm{T} 0]$ & 0.640 & 7 & 0.001 & Not normal & Уiлкоксонаi \\
$\mathrm{Cr}[\mathrm{T} 1-\mathrm{T} 0]$ & 0.672 & 7 & 0.002 & Not normal & Student's \\
$\mathrm{Mn}[\mathrm{T} 1-\mathrm{T} 0]$ & 0.760 & 7 & 0.016 & Normal & Student's \\
$\mathrm{Tl}[\mathrm{T} 1-\mathrm{T} 0]$ & 0.911 & 7 & 0.402 & Normal & Student's \\
$\mathrm{Ba}[\mathrm{T} 1-\mathrm{T} 0]$ & 0.904 & 7 & 0.353 & Normal & Student's \\
$\mathrm{Ni}[\mathrm{T} 1-\mathrm{T} 0]$ & 0.898 & 7 & 0.318 & Normal & Student's \\
$\mathrm{Sr}[\mathrm{T} 1-\mathrm{T} 0]$ & 0.840 & 7 & 0.099 & Normal &
\end{tabular}

The results of the dynamics evaluation in the experimental group (in the state of artificial hypobiosis) using Student's criterion for pair data are given in Table 8.

Table 8

Results of the dynamics evaluation in the experimental group using Student's criterion for pair data

\begin{tabular}{|c|c|c|c|c|c|}
\hline Comparable pair & $\mathbf{t}$ & df & p-meaning & $\begin{array}{c}\text { Average } \\
\text { differences }\end{array}$ & $\begin{array}{c}\text { Conclusion on the significance } \\
\text { of differences * }\end{array}$ \\
\hline $\mathrm{K} \_1-\mathrm{K} \_2$ & 4.241 & 6 & 0.005 & 122.282 & Significant \\
\hline $\mathrm{Na} \_1-\mathrm{Na} \_2$ & -7.535 & 6 & 0.000 & -190.223 & Significant \\
\hline Ca_1-Ca_2 & 4.169 & 6 & 0.006 & 7.871 & Significant \\
\hline Mg_1-Mg_2 & 3.804 & 6 & 0.009 & 8.969 & Significant \\
\hline $\mathrm{Zn} \_1-\mathrm{Zn} \_2$ & 3.333 & 6 & 0.016 & 1.259 & Significant \\
\hline Mn_1-Mn_2 & 0.672 & 6 & 0.527 & 0.032 & Not significant \\
\hline $\mathrm{T} 1 \_1-\mathrm{T} 1 \_2$ & -3.073 & 6 & 0.022 & -0.118 & Significant \\
\hline $\mathrm{Ba} \_1-\mathrm{Ba} \_2$ & -3.679 & 6 & 0.010 & -0.120 & Significant \\
\hline $\mathrm{Ni} \_1-\mathrm{Ni} \_2$ & -45.842 & 6 & 0.000 & -0.097 & Significant \\
\hline Sr_1 - Sr_2 & -5.203 & 6 & 0.002 & -0.014 & Significant \\
\hline
\end{tabular}

Note: * - The conclusion is made at a significance level of 0.05 
The results of assessing the significance of the dynamics in a group using Student's criterion for pair data are given in Table 8, and with the help of the Wilcoxon signed-rank (Table 9, 10).

Table 9

Results of evaluation of dynamics in the experimental (hypopoietic) group using the Wilcoxon signed-rank criteria

\begin{tabular}{cccc}
\hline Comparable pair & $\mathbf{Z}$ & p-meaning & Conclusion on the significance of differences* \\
\hline $\mathrm{Fe}_{-} 2-\mathrm{Fe}_{-} 1$ & -2.388 & 0.017 & Significant \\
$\mathrm{Cu}$ 2 $-\mathrm{Cu}_{-} 1$ & -1.016 & 0.310 & Not significant \\
$\mathrm{Cr}$ 2 $-\mathrm{Cr}$ 1 & -2.384 & 0.017 & Significant
\end{tabular}

Note: the conclusion is made at a significance level of 0.05

Table 10

Rank statistics derived from the application of the Wilcoxon signed-rank criteria

\begin{tabular}{ccccc}
\hline $\begin{array}{c}\text { Pair of variables, } \\
\text { which are compared }\end{array}$ & Statistical indicators & n & Average rank & Sum of ranks \\
\hline & Negative ranks & 22 & 21.18 & 466 \\
$\mathrm{Fe}[\mathrm{T} 0] \& \mathrm{Fe}[\mathrm{T} 1]$ & Additional ranks & 17 & 18.47 & 314 \\
& Connections & 1 & & 212 \\
& Total & 40 & 15.14 & 383 \\
$\mathrm{Cu}[\mathrm{T} 0] \& \mathrm{Cu}[\mathrm{T} 1]$ & Negative ranks & 14 & 19.15 & 487.5 \\
$\mathrm{C}$ & Additional ranks & 20 & & 332.5
\end{tabular}

Note: parameter [T1]<parameter [T0]; parameter [T1]> parameter [T0]; parameter [T1]=parameter [T0]

\section{Discussion}

As it is known from previous studies, in the state of artificial hypobiosis, the inhibition of the vital activity of a living organism occurs: the intensity of cardiac contractions decreases, rectal body temperature decreases to $-16{ }^{\circ} \mathrm{C}$, mobility of the body completely disappears.

As a result of the studies, the growth of sodium was also found. The reasons for this are likely to be the support of the water-salt balance, because it provides for the conservation of mineral substances in the blood in the soluble state [9].

Also, the experiment showed that the state of artificial hypobiosis decreases the content of Nickel. This, probably, can be explained by the decrease in oxidative-reducing processes in the tissues of the body, which is explained by hypoxia [10].

Causes of sodium growth may be fluid retention in the body, since under artificially-created hypotonic conditions fluidity of the fluid in the body decreases, which is quite positive when conducting short-term surgical interventions. It should be noted that after the release of hypobiosis, increased excitability of rats was observed [11].

At the same time, there was an increase in the level of iron (Ferrum). This is due to oxygen starvation - hypoxia, it is obvious that in this case, the body tries to compensate for the lack of oxygen by the increased production of haemoglobin [12]. 
Investigations of the elemental blood composition in general showed that changes occurring in the body under hypothetical conditions are not critical to the organism, but only characterize the physiological changes occurring in hypoxia, hypercapnia, hypothermia [13].

It is also necessary to study the micro- and macro-elemental composition of the liver and heart of rats, since these two organs play an important role in maintaining the steady homeostasis of the organism [14]. Therefore, this will give an opportunity to more broadly assess the safety of hypobiosis.

\section{Conclusions}

1. As a result of the study, it was found that artificial hypobiosis suppress metabolic processes of the body, reduces the frequency of heart contractions, mobility, painful sensations also disappear, which suggests that it is in this state that short-term surgical interventions are possible [15].

2. It was found that changes in the elemental composition of the rat heart in the experimental group are not critical, which can negatively affect the vital activity of the organism. Based on these conclusions, we can assume that hypobiosis - as a general anaesthetic method can be used in clinical practice [16].

3. The heterogeneity of the statistical data of the results of the experimental hypobiotic groups according to the Mann-Whitney criterion was demonstrated in such elements as: Potassium, Sodium, Ferrum, Calcium, Chromium, Strontium.

4. Investigation of the elemental blood composition of rats by artificial hypobiosis will allow to understand the differences in micro- and macro-elemental changes occurring in the body and thus will enable to assess the safety of the use of hypobiosis in clinical practice [17].

\section{Acknowledgment}

Special thanks go to the State University "Institute of Pharmacology and Toxicology of the National Academy of Medical Sciences of Ukraine", on the basis of which the research data were carried out.

\section{References}

[1] Banerjee, P. S., Ma, J., Hart, G. W. (2015). Diabetes-associated dysregulation ofO-GlcNAcylation in rat cardiac mitochondria. Proceedings of the National Academy of Sciences, 112 (19), 6050-6055. doi: 10.1073/pnas.1424017112

[2] Morozova, V. S. (2013). Functioning of the antioxidant system of rat myocardium for condition of artificial hypobyosis. Bulletin of Biology and Medicine, 3 (2), 103.

[3] Melnychuk, D. O., Melnychuk, S. D., Arnauta, O. V. (2004). Influence of carbon dioxide on the environment preservation of red blood cells in stored blood of animals. Scientific Bulletin of NAU, 75, 163-165.

[4] Melnychuk, S. D. (2001). Key figures acid-base status blood and metabolic hibernation and when general anesthesia for the amputation. Ukrainian Biochemical Journal, 73 (6), 80-83.

[5] Melnychuk, S. D., Melnychuk, D. O. (2007). Animal dormancy (molecular mechanisms and practical for Agriculture and Medicine). Kyiv: Publishing Center NAU, 220.

[6] Glanz, S. (1999). Medico-biological statistics. Moscow: Practice, 460.

[7] Logvinovich, O. S., Aksenova, G. E. (2013). Ornithine decarboxylase in mammalian organs and tissues at hibernation and artificial hypobiosis. Zh Obshch Biol, 74 (3), 180-189.

[8] Pogorelov, M. V., Bumeister, V. I., Tkach, G. F., Du Bonchev, S., Sikor, V. Z., Sukhodub, L. F., Danilchenko, S. M. (2010). Macro and microelements (exchange, pathology and methods of definition). Publishing House of SSU, 96.

[9] Guglielmino, K., Jackson, K., Harris, T. R., Vu, V., Dong, H., Dutrow, G. et. al. (2012). Pharmacological inhibition of soluble epoxide hydrolase provides cardioprotection in hyperglycemic rats. American Journal of Physiology-Heart and Circulatory Physiology, 303 (7), 853-862. doi: 10.1152/ ajpheart.00154.2012 
[10] De Oliveira, R. W., Julian, G. S., Perry, J. C., Tufik, S., Chagas, J. R. (2018). Chronic intermittent hypoxia induces changes on the expression and activity of neprilysin (EC 3.4.24.11) in the brain of rats. Neuroscience Letters, 678, 43-47. doi: 10.1016/j.neulet.2018.04.045

[11] Jastroch, M., Giroud, S., Barrett, P., Geiser, F., Heldmaier, G., Herwig, A. (2016). Seasonal Control of Mammalian Energy Balance: Recent Advances in the Understanding of Daily Torpor and Hibernation. Journal of Neuroendocrinology, 28 (11). doi: 10.1111/jne.12437

[12] Storey, K. B., Storey, J. M. (2017). Molecular Physiology of Freeze Tolerance in Vertebrates. Physiological Reviews, 97 (2), 623-665. doi: 10.1152/physrev.00016.2016

[13] Zhukov, A. F., Kolosova, I. F., Kuznetsov, V. V. (2001). Analytical Chemistry. Physical and physicochemical methods of analysis. Moscow: Chemistry, 496.

[14] Kamyshnikov, V. S. (2004). Handbook of clinical and biochemical studies, and laboratory diagnosis. Moscow: MEDpress-Inform, 524-526.

[15] Ketsa, O. V., Shmarakov, I. O., Marchenko, M. M. (2016). Lipid peroxidation in cardiac mitochondrial fraction of rats exposed to different supplementation with polyunsaturated fatty acids. Biomeditsinskaya Khimiya, 6 2(1), 50-55. doi: 10.18097/pbmc20166201050

[16] Nazarenko, G. I., Kiskun, A. A. (2002). Clinical evaluation of laboratory results. Moscow: Medicine, 535-544.

[17] Nelson, D. L., Cox, M. M. (2017). Lehninger Principles of Biochemistry. New York: W. H. Freeman, 1328 . 